\title{
Numerical simulation and performance assessment of an absorption solar air-conditioning system coupled with an office building
}

\author{
Sébastien THOMAS*, Philippe ANDRE \\ University of Liège, Department of sciences and environmental management \\ avenue de Longwy, 185, 6700 Arlon (Belgium) \\ *Corresponding author : sebastien.thomas@ulg.ac.be
}

\section{ABSTRACT}

To minimize environmental impact and $\mathrm{CO}_{2}$ production associated with air-conditioning, it is reasonable to evaluate the prospects of a clean energy source. Solar energy, via thermal collectors can provide a part of the heating needs. Moreover, it can drive absorption chiller in order to satisfy the cooling needs of buildings. The objective of the work is to evaluate accurately the energy consumption of an air conditioning system including a solar driven absorption chiller. The complete simulation environment includes the absorption chiller itself, the cooling tower, the solar collectors field, heater, storage devices, pumps, heating-cooling distribution, emission system and building. The modelling of each subsystem is detailed. TRNSYS software modular approach provides the possibility to model and simulate this complete system.

Keywords: TRNSYS, solar cooling, absorption

\section{INTRODUCTION}

Solar air conditioning is a good way to use renewable energy instead of fossil fuels to meet heating and cooling needs of buildings. It implies a decrease in energy consumption and CO2 rejection. There are currently around 400 systems (Sparber et al., 2009) in operation all over the world. A lack of awareness of such technologies is still encountered.

The development of solar air-conditioning (SAC) technology is closely linked to its economical profitability. To check what the real benefits of SAC installation are, it is important to compute the energy savings as well as their essentials parameters (Casals, 2006).

Previous works (Hensen 1991, Barbosa 2008) about analysis of heating and cooling consumption suggest considering an integral approach to evaluate energy savings. Moreover, performance is greatly depending on external conditions and on cooling load dynamics in SAC systems (Bujedo 2008, Pollerberg 2008). It is thus important to think about the whole system (Mugnier 2002, Eicker 2008).

This study concerns a common solar air conditioning system. A solar collector field provides hot water to a storage tank. Hot water then can be used for heating the building or feeding an absorption machine. This last device is used to produce cold water (Herold, 1996). As solar energy is not enough to heat and cool the whole building through the year, back up systems are used. To heat, a conventional gas boiler is used. To cool back-up two choices can be assessed: heating water to feed the absorption chiller or use of a classical vapour compression chiller (electricity driven). A previous work (Thomas et al., 2009a) has pointed out that the 
second choice is the best one from an energy point of view; it will be implemented in this study.

A complete simulation environment is presented in this paper, it is implemented in TRNSYS (2006). Generally, the analysis is focused on the basic heating and cooling load of the building. Here, numerous other devices and effects are modelled and connected together:

- $\quad$ Building

Internal gains, light dimming, moveable solar protections, latent loads

- $\quad$ Hot and Cold distribution and emission

Fan coil units, Pumps, Pipes

- $\quad$ Hot and cold production and storage

Gas boiler, Solar loop, Hot water storage, absorption chiller, cooling tower, vapour compression chiller (for back up only).

- Climate

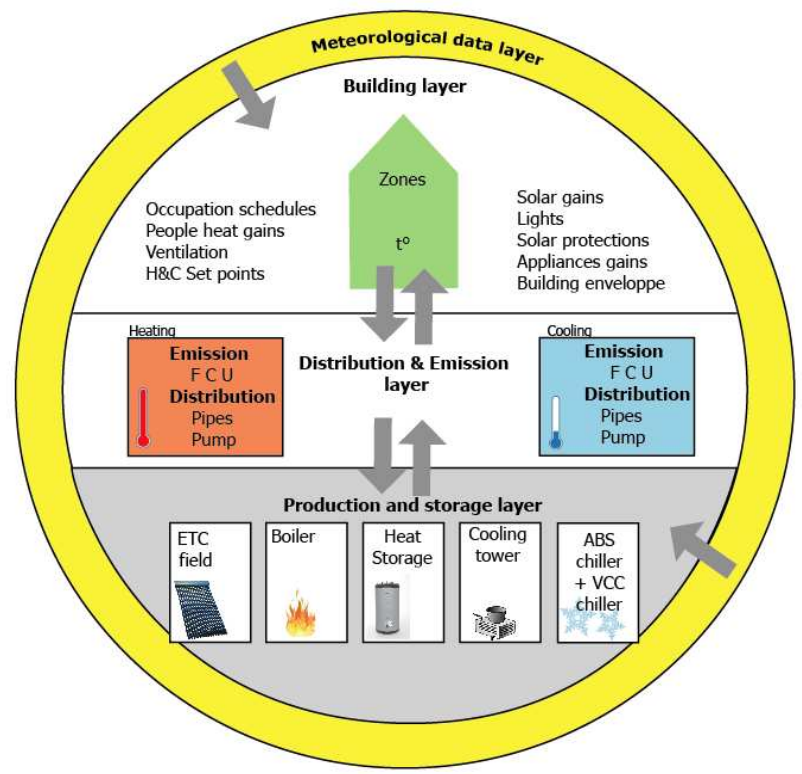

Figure 1: Simulation layers

These four subsystems constitute the simulation environment layers detailed in figure 1 . This kind of implementation gives the opportunity to analyse relations between the absorption chiller and the building. Moreover, the modularity of this approach is suitable with model switching. The different layers modelling and simulation are described in the next paragraphs.

In order to easily compare energy consumptions, a reference case called "classical airconditioning" is defined. It includes an electricity driven vapour compression chiller for cold production and a boiler for heating but neither solar panels nor storage devices. Comparison is done on net energy consumption and primary energy consumption. The assessment deals also with the electricity consumption of lighting system, appliances and ventilation system. In this way the global energy use of the building is considered.

\section{BUILDING MODELLING}

The analysis deals with a theoretical building representative of existing large office buildings in Europe. It was defined by Stabat (2007) in the frame of the IEA-ECBCS annex 48 project called Heating Pumping and Reversible Air Conditioning. It is a twelve identical floors, 
$15000 \mathrm{~m}^{2}$ building with an average of 1000 persons occupancy. From the modelling point of view, only one floor is modelled but all the floors can be treated similarly. A three floor building is considered for the solar collector field design (see $§ 5.4$ ).

\subsection{Geometrical description}

Geometrical description is presented below on figure 2. Five zones are considered for a total of $1250 \mathrm{~m}^{2}$.
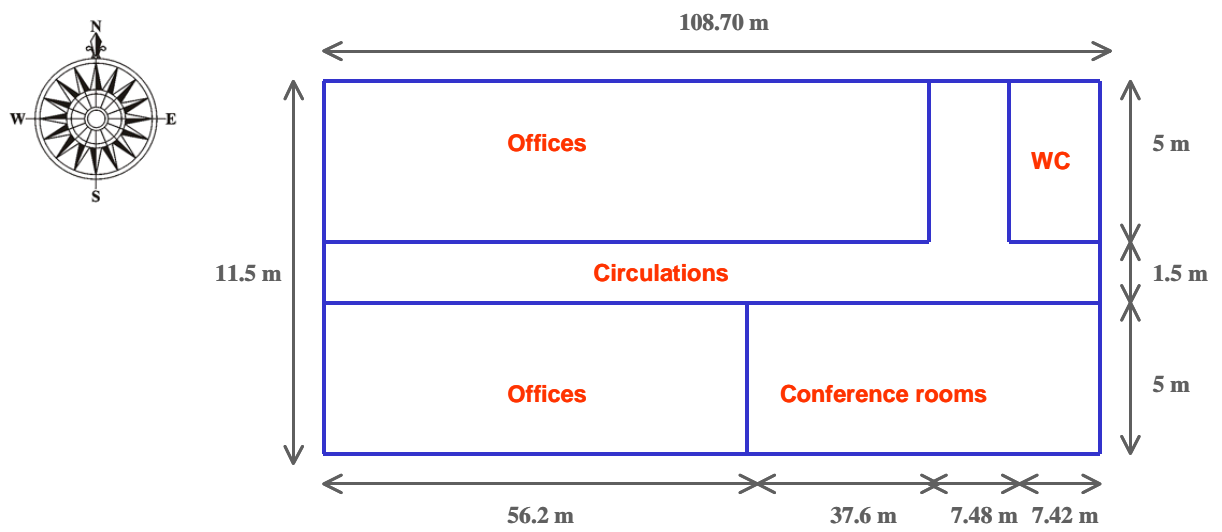

Figure 2: Typical floor for office building (Stabat, 2007)

\subsection{Envelope}

The building studied is representative of existing buildings, the insulation is thus not very efficient. North and South façade are similarly largely glazed while East and Western are blind walls. Rooms are 3 meters high while windows take up 2 meters. Wall constitution and U values are described in table 1 .

Table 1: Wall constitution

\begin{tabular}{|c|c|c|}
\hline & Constitution \\
\hline $\begin{array}{c}\text { Outside } \\
\text { Wall }\end{array}$ & $\begin{array}{l}\text { Outside layer : Cement } 0.13 \mathrm{~m} \\
\left(\rho=1900 \mathrm{~kg} / \mathrm{m}^{3}, \lambda=0.58 \mathrm{~W} /(\mathrm{m} . \mathrm{K}), c_{p}=1000 \mathrm{~J} /(\mathrm{kg} . \mathrm{K})\right) \\
\text { Insulating material } 0.024 \mathrm{~m} \\
\left(\rho=56 \mathrm{~kg} / \mathrm{m}^{3}, \lambda=0.029 \mathrm{~W} /(\mathrm{m} . \mathrm{K}), c_{p}=1220 \mathrm{~J} /(\mathrm{kg} . \mathrm{K})\right) \\
\text { Inside layer: plaster } 0.012 \mathrm{~m} \\
\left(\rho=1860 \mathrm{~kg} / \mathrm{m}^{3}, \lambda=0.72 \mathrm{~W} /(\mathrm{m} . \mathrm{K}), c_{\mathrm{p}}=840 \mathrm{~J} /(\mathrm{kg} . \mathrm{K})\right)\end{array}$ & 0.8 \\
\hline Windows & Double glazing of $4 \mathrm{~mm}$ width for each glazing and $8 \mathrm{~mm}$ air space. & 2.95 \\
\hline $\begin{array}{l}\text { Floor \& } \\
\text { ceiling }\end{array}$ & Cement $0.1 \mathrm{~m}\left(\rho=1900 \mathrm{~kg} / \mathrm{m}^{3}, \lambda=0.58 \mathrm{~W} /(\mathrm{m} . \mathrm{K}), \mathrm{c}_{\mathrm{p}}=1000 \mathrm{~J} /(\mathrm{kg} . \mathrm{K})\right)$ & 5.8 \\
\hline
\end{tabular}




\begin{tabular}{|c|l|c|}
\hline \multirow{2}{*}{ Roof } & $\begin{array}{l}\text { Outside layer : Cement } 0.13 \mathrm{~m} \\
(\rho=1900 \mathrm{~kg} / \mathrm{m} 3, \lambda=0.58 \mathrm{~W} /(\mathrm{m} . \mathrm{K}), \mathrm{cp}=1000 \mathrm{~J} /(\mathrm{kg} . \mathrm{K})) \\
\text { insulating material } 0.06 \mathrm{~m} \\
(\rho=56 \mathrm{~kg} / \mathrm{m} 3, \lambda=0.029 \mathrm{~W} /(\mathrm{m} . \mathrm{K}), \mathrm{cp}=1220 \mathrm{~J} /(\mathrm{kg} \cdot \mathrm{K})) \\
\text { Inside layer: plaster } 0.012 \mathrm{~m} \\
(\rho=1860 \mathrm{~kg} / \mathrm{m} 3, \lambda=0.72 \mathrm{~W} /(\mathrm{m} . \mathrm{K}), \mathrm{cp}=840 \mathrm{~J} /(\mathrm{kg} \cdot \mathrm{K}))\end{array}$ & 0.4 \\
\hline $\begin{array}{l}\text { Inner } \\
\text { walls }\end{array}$ & plaster $0.02 \mathrm{~m}(\rho=1860 \mathrm{~kg} / \mathrm{m} 3, \lambda=0.72 \mathrm{~W} /(\mathrm{m} . \mathrm{K}), \mathrm{cp}=840 \mathrm{~J} /(\mathrm{kg} \cdot \mathrm{K}))$ & 36 \\
\hline
\end{tabular}

\subsection{Internal heat gains}

\subsubsection{People}

Offices and Meeting rooms have two different schedules and occupancy rate. The sizing of the offices is defined as one person per $12 \mathrm{~m}^{2}$ ( 1 person per $3.5 \mathrm{~m}^{2}$ for conference room). The sensible heat released by each person is supposed to be $105 \mathrm{~W}$ and the moisture release is $0.09 \mathrm{~kg} / \mathrm{h}$ (Stabat, 2007). Occupancy profile are defined in figure 3 . The ratio is the current occupancy divided by sizing value. No consideration about holiday is taken into account. During weekend, appliances gains as well as occupancy are null.

\subsubsection{Appliances}

Similarly to previous paragraph, appliances gains are defined. Figure 3 notifies the appliances ratio for a sizing value is $15 \mathrm{~W} / \mathrm{m}^{2}$. The appliances are essentially computers; these gains exist only in the offices zones.

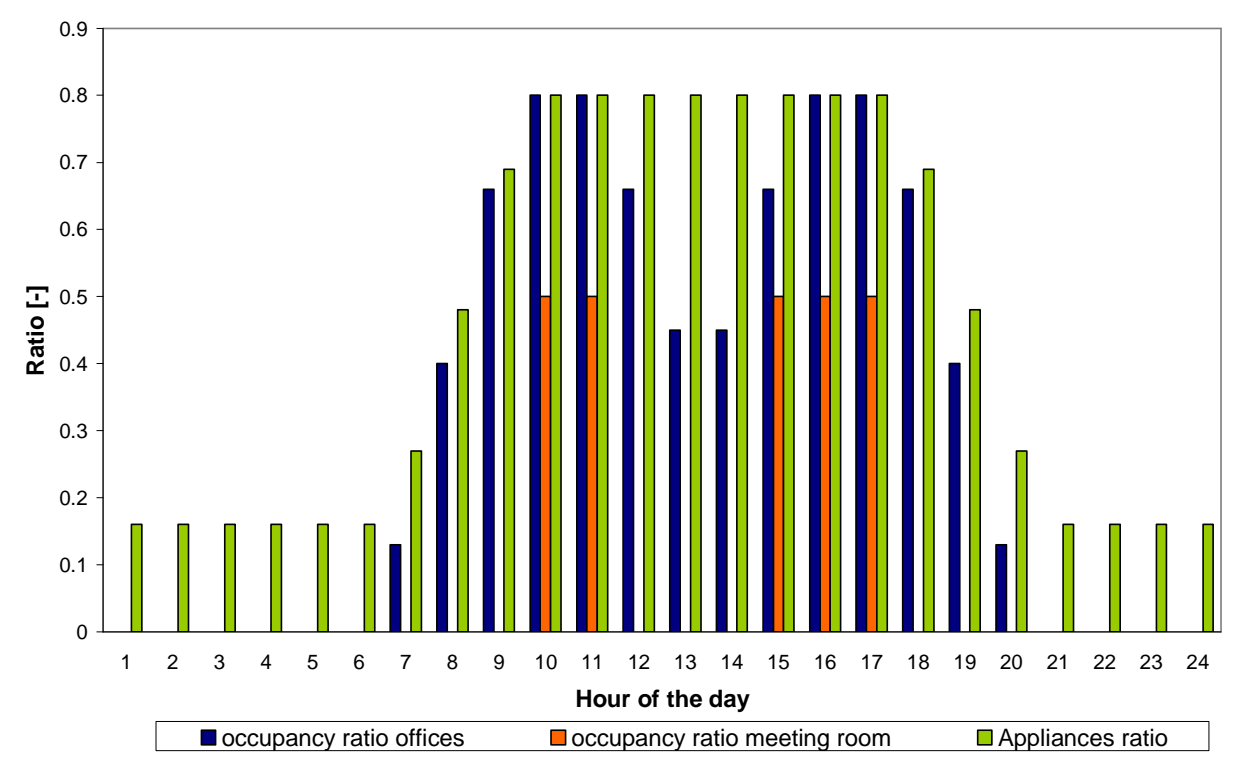

Figure 3: Schedules for occupancy and appliances (Stabat, 2007) 


\subsubsection{Lighting system}

The lighting power is set to $18 \mathrm{~W} / \mathrm{m}^{2}$ in offices and conference rooms, $12 \mathrm{~W} / \mathrm{m}^{2}$ in the circulations and $6 \mathrm{~W} / \mathrm{m}^{2}$ in the toilets. Based on the work of Alessandrini (2006) the use of artificial lighting depends on natural light available for workers. Between 0 and 100 Lux, the use of artificial lighting is $90 \%$; between 100 and 700 Lux, it drops linearly to $30 \%$; it falls linearly to $0 \%$ when available natural light is 2500 Lux. Available light is computed with TRNSYS regarding the solar energy through the windows. A basic law is implemented and considers whole solar radiation spectrum as visible light. Light is switched on only during occupancy, in toilets and circulation zone it is always on from 6am to $7 \mathrm{pm}$.

\subsection{Solar protections}

Manual external solar protections are modelled. They implement the behaviour of the people in the zones (Allessandrini, 2006). When the solar protections are completely closed, the energy transmission is $20 \%$. The use opening of solar protections is achieved by the user; depending on the outside luminance, the solar protections are closed from 7 to $45 \%$. The position of solar protections during non occupancy is defined as equal to those in the last hour of occupancy.

\subsection{Ventilation and infiltration}

Constant mass flow is blown in the building during occupancy (figure 4), it corresponds to 25 $\mathrm{m}^{3} / \mathrm{h}$ fresh air per person for offices and $30 \mathrm{~m}^{3} / \mathrm{h}$ per person for conference room. No heat recovery is implemented. When there is no occupancy, the mechanical ventilation is switched off; infiltration is then equal to 0.373 volume per hour. For all zones except conference room the power of ventilator is $330 \mathrm{~W}$ (single flux ventilation). For conference room, a double flux ventilation without recovery is implemented, it leads to fan power 2 times $470 \mathrm{~W}$ $\left(0.21 \mathrm{~W} / \mathrm{m}^{3} / \mathrm{hr}\right)$.

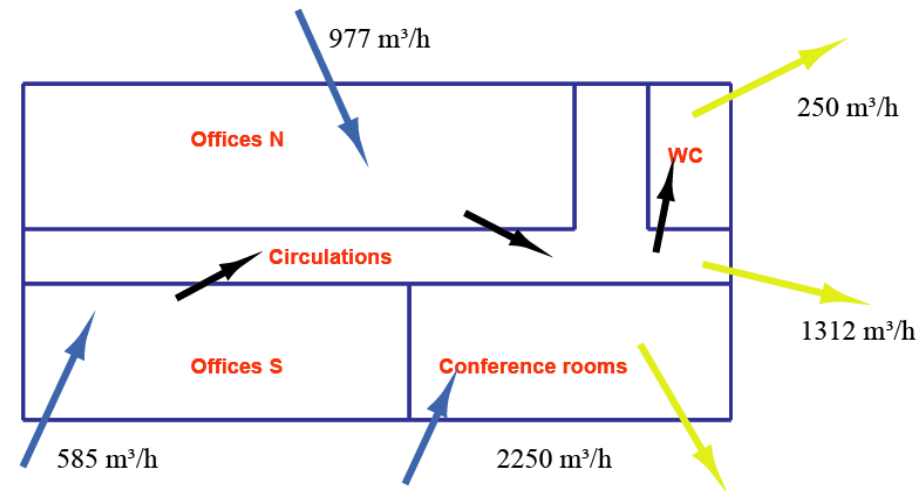

Figure 4: Ventilation mass flows for one floor

\subsection{Temperature and humidity set points}

The set points for heating are $21^{\circ} \mathrm{C}-40 \%$ relative humidity in all heated zones (offices and conference room) during occupation. All over the year, the minimal temperature in those zones is $15^{\circ} \mathrm{C}$. For cooling, the set point is $24^{\circ} \mathrm{C}-60 \%$ relative humidity during occupancy. According to the DIN 1946 German regulation, a $26^{\circ} \mathrm{C}$ room air temperature is acceptable for people. If external temperature is greater than $29^{\circ} \mathrm{C}$, a higher internal temperature is comfortable. There is no upper limit zone temperature for other periods. Two simulations are run, one with the common temperature set point $\left(24^{\circ} \mathrm{C}\right)$ and the other one with DIN 1946 regulation $\left(26^{\circ} \mathrm{C}\right)$. 


\section{H\&C EMISSION AND DISTRIBUTION}

This part focuses on the heat and cold emission and distribution layer of a common office building. It does not integrate any devices facilitating implementation of solar airconditioning (e.g. cooling ceiling). Links with other layers are drawn on figure 1 whereas the implementation of this layer is described on figure 5. The TRNSYS types numbers are also mentioned. In the building analyzed, heating and cooling load are sometimes simultaneous. Heating and cooling systems have their own pipe network.

The link with building layer consists in heating and cooling sensible and latent energy given in each room by the Fan coil units (FCU) and pipe losses. The temperature of each room acts as an input for FCU control. The links with production layer are the temperature and the mass flow for each network

\subsection{Pipes}

As described in (Stabat, 2007), the hot or cold network is summed up into two pipes (one supply, one return) with a total length of 65 meters each. Their $\mathrm{U}$ value is $0.28 \mathrm{~W} /(\mathrm{m} \mathrm{K})$. Losses to the ambient $\left(22^{\circ} \mathrm{C}\right.$ all over the year) are $80 \%$ recovered by the building.

\subsection{Pumps}

Pressure drop, pump efficiency (40\%) and mass flow (depending on the number of fan coil units and their characteristics) are defined. The power of the heat network pump is $475 \mathrm{~W}$ while that of the cold pump is $1485 \mathrm{~W}$. The first pump is in operation only when there are heating needs while the second is permanently ON. Moreover, the entire pump power is transferred to fluid.

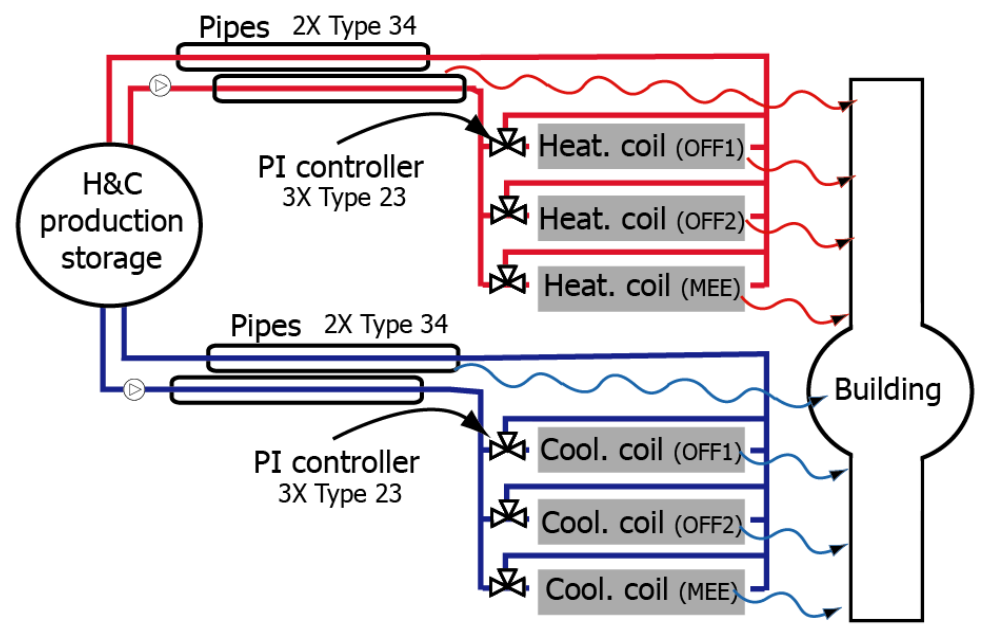

Figure 5: Emission distribution network implementation scheme

\subsection{Fan coil units (FCU)}

The heating-cooling coils are effectively transferring heat-cold to the building. The control is achieved by a valve adjusting the mass flow in order to satisfy the room temperature set point.

In order to model as accurately as possible the heat-cold emission, it has been decided to create a new fan coil model with behaviour as close as possible to the manufacturer data (we suppose it is closed to the reality). To achieve this, it is common to evaluate a polynomial estimation of the real behaviour (Barbosa, 2008). The chosen fan coil (CARRIER, 2007) nominal characteristics are specified in table 2. The objective of the FCU model is to evaluate 
the heat or cold provided by the coil according to some variables. These are different for heating and cooling: for heating coil, sensible heat depends on water mass flow and differences between water inlet temperature and room dry bulb temperature; for cooling coil, sensible cooling load is cooling coil entering temperature, room temperature. Normally the temperature gap between supply and return cold water should be taken into account but this involved convergence issues.

The sensible heating power according to mass flow and temperature gap between water supply temperature and room air temperature is presented on figure 6. Polynomial approximation computed with Matlab (Matlab, 2007) gives a mean error of $0.9 \%$ when evaluating the whole operating points given by the manufacturer.

Table 2: Fan coil characteristics* for $42 N 60$ model (nominal operation)

\begin{tabular}{|l|c|c|}
\hline & HEATING & COOLING \\
\hline Water mass flow & $0.25 \mathrm{~kg} / \mathrm{s}$ & $0.23 \mathrm{~kg} / \mathrm{s}$ \\
\hline Dry bulb air temp & $\mathrm{T}$ & $27^{\circ} \mathrm{C}$ \\
\hline Supply water temp & $\mathrm{T}+60^{\circ} \mathrm{C}$ & $7^{\circ} \mathrm{C}$ \\
\hline Return temp & - & $12^{\circ} \mathrm{C}$ \\
\hline Sensible capacity & $8400 \mathrm{~W}$ & $4880 \mathrm{~W}$ \\
\hline
\end{tabular}

*centrifugal fan at high speed.

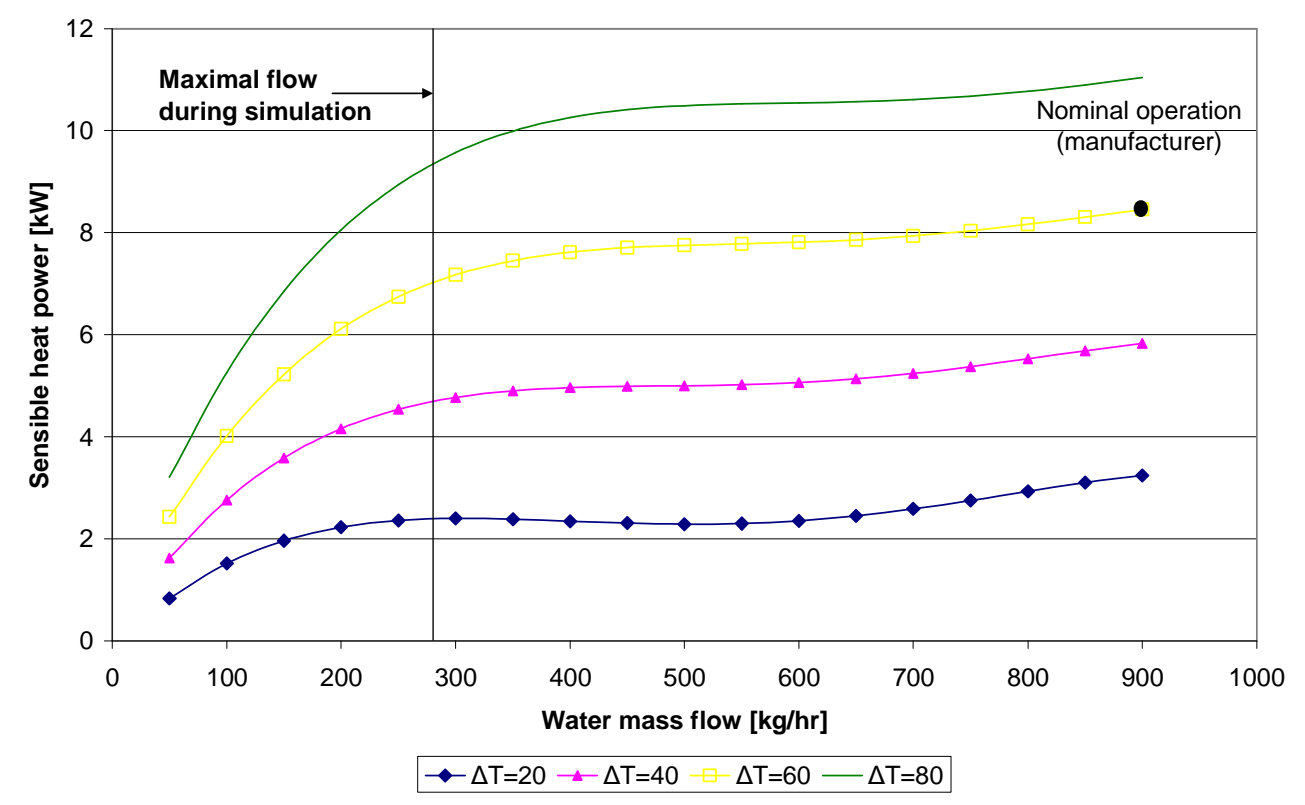

Figure 6: Polynomial approximation of FCU power (where $\triangle T=$ Twater supply- Troom)

Other coil models have been tested:

Some of the existing models of heating cooling coil in TRNSYS are tuned with only one parameter: heat exchanger efficiency or bypass air fraction 
(Klein, 2007). These models are not accurate for the whole range of FCU use (16.5\% mean error for Type $670-10.2 \%$ for type 753$)$

Other models read manufacturer data in an external file (e.g. type 697b). This is a good way to have the real behaviour of a fan coil. However, it requires translating all the working points to a suitable file format (this can be source of numerous errors).

The total number of fan coils has been chosen based on the highest cooling or heating loads and on FCU power at nominal capacity. This gives 25 FCU for the entire floor. They are distributed into the three zones: 7 for Offices South, 11 for Offices North, 7 for Meeting Room (MEE). All the FCU of the same zone are controlled similarly.

Fan power is $113 \mathrm{~W}$ per FCU. It is switched on only when there is heating or cooling load in the zone.

Latent load is not handled by the model presented in this paragraph because of the lack of manufacturer data. Nevertheless, it is taken into account in the water loops. Latent load computed by TRNSYS building model to maintain the set point is translated into a temperature difference in water flow before the return pipe. This is a very simple way to treat this load but it counts for around only $10 \%$ of the total cooling load. A future better FCU model should handle the latent load.

\section{H\&C PRODUCTION AND STORAGE}

This section highlights the heat and cold production layer of the simulation. This layer contains elements of which the most important are displayed on figure 7. Previous paragraphs were dealing with conventional building and system while this part is really speaking about the use of solar energy to heat-cool the space. Heat is provided by a boiler and a solar collector field while cold is produced by an absorption chiller and a conventional vapour compression chiller.

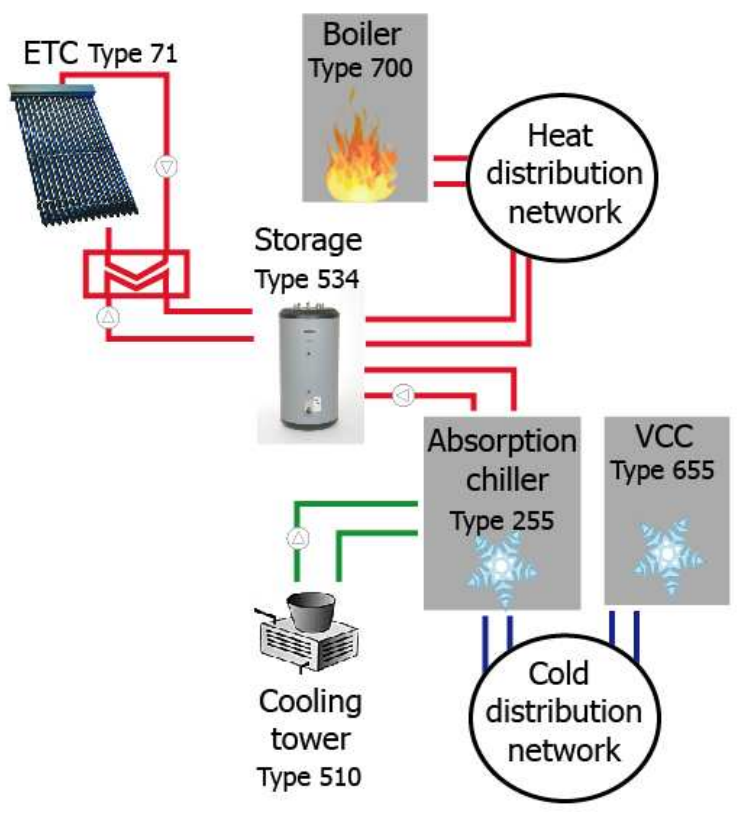

Figure 7: Production and storage layer

The links between this layer and distribution are temperature and water flow rates of hot and cold water. 


\subsection{Absorption chiller}

The heat provided by solar collectors is stored and feeds an absorption chiller to produce cold water. Among all kind of thermally driven chiller available on the market, a lithium bromide water absorption chiller was chosen. This type of machine is mostly used in offices solar air conditioning systems (Sparber et al., 2009).

Absorption chiller behaviour has been implemented in a new TRNSYS type 255 (nearly the same as existing TRNSYS type 107) based on manufacturer curves (YAZAKI, 2008) of a 105 $\mathrm{kW}_{\text {cold }}$ absorption chiller $\left(C O P_{\text {rated }}=0.695\right)$. It is fitted to the modelled floor cooling demand.

The existing model (type 107) is modelling the energy balance, but not the chiller inertia nor other dynamic effects. Absorption chiller works with three energy flows : High temperature flow $\left(>70^{\circ} \mathrm{C}\right)$ drives the machine ; cold flow $\left(7-12^{\circ} \mathrm{C}\right)$ satisfies the building cooling load ; rejection flow at medium temperature $\left(35-40^{\circ} \mathrm{C}\right)$ is rejected to the atmosphere.

The model solves this energy balance, the relationship between the hot and cold flow is governed by the thermal Coefficient Of Performance (equation 1). Furthermore, the maximum cold flow is defined according to the current conditions of hot and rejection water temperatures (figure 8). The model reads these two variables in a data file to compute the energy balance. Figure 8 shows the different points picked up from manufacturer data for one rejection temperature and cold water set point. Data file for types 107 and 255 requires fraction of nominal capacity $\left(f_{n c}\right)$ and fraction of design energy input $\left(f_{d e i}\right)$. So, according the equations 2 and 3, we can compute available $\mathrm{Q}_{\text {cold }}$ and $\mathrm{Q}_{\text {hot }}$ with the data file and the two parameters $\mathrm{COP}_{\text {rated }}$ and $\mathrm{Q}_{\text {cold rated }}$

$$
\begin{gathered}
C O P=\frac{Q_{\text {cold }}}{Q_{\text {hot }}} \\
Q_{\text {cold }}=Q_{\text {cold }, \text { rated }} \cdot f_{n c} \\
Q_{\text {hot }}=\frac{Q_{\text {cold }, \text { rated }}}{C O P_{\text {rated }}} \cdot f_{\text {dei }}
\end{gathered}
$$

The model analysis revealed discrepancies in type 107. Firstly, in such chillers, the rated cooling power is generally not the highest cooling power (figure 8). Nevertheless, in type 107, fraction of nominal capacity is computed based on the rated capacity and is limited to 1 (Klein, 2007). It is then required to enter both parameters (COP and $\mathrm{Q}_{\text {cold) }}$ at maximum capacity conditions instead of rated conditions. Secondly the part load operation (fraction of nominal capacity) is independent of current condition (three flows temperature). It implies a non convenient way to create the data file.

A new type numbered 255 was consequently developed; it has a second call to the external data file. The first call is used for discovering the maximum capacity at current conditions, the second call for the part load evaluation. In this way, we are able to reproduce the behaviour described by the manufacturer data.

There are still issues in the absorption chiller simulation. Due to the lack of manufacturer data the part load operation is not handled correctly; thermal COP is assumed to be identical whatever the load. Additionally, while the cooling demand is lower than the cooling capacity, the chiller produces the exact cold quantity to reach the set point $\left(7^{\circ} \mathrm{C}\right.$ in this case $)$; it means 
there is no minimum cooling power. Finally, to be consistent with reality, the temperature levels must stay in the range of the manufacturer data. It could be interesting to evaluate points outside of this data.

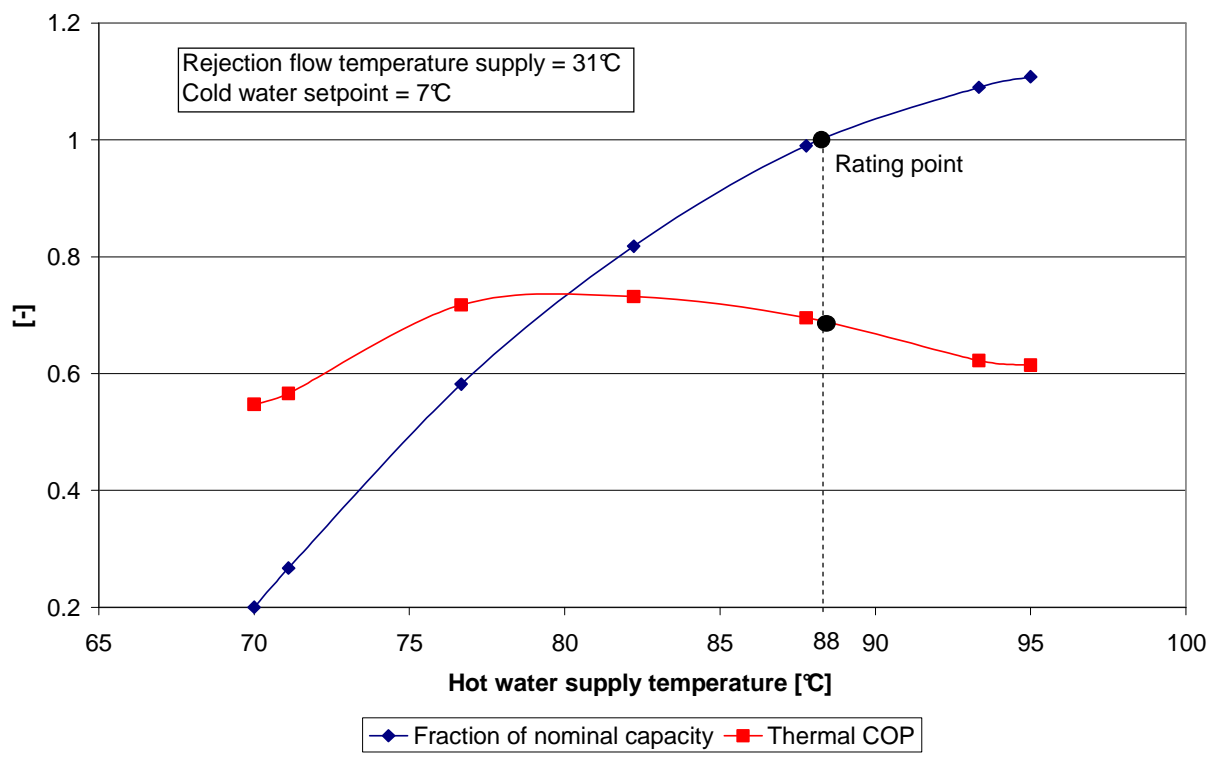

Figure 8: Thermal COP and fraction of nominal capacity of absorption chiller.

The cooling production devices must have clever control strategies to satisfy the cooling needs while reducing energy consumption (S. Thomas et al. , 2009a and 2009b). Firstly, the absorption chiller is switched OFF and vapour compression chiller switched ON when the water on the top of storage is lower than a specified threshold. Secondly the threshold is computed according to the cooling load. Basically while the cooling load is not high, absorption hot water supply doesn't have to be so high (figure 8). Practically, depending on the cooling network return temperature, the minimum absorption chiller hot water supply temperature is between 70 and $83^{\circ} \mathrm{C}$. Finally, to avoid ON/OFF switching between both chillers, a hysteresis controller with a $3^{\circ} \mathrm{C}$ deadband is implemented.

\subsection{Heat storage}

The fundamental element of the production storage layer is the storage tank (TRNSYS type 534); as shown on figure 7, three circuits are directly connected to it (no heat exchanger in the tank): solar collector, building heating network and absorption chiller hot water loop. The solar radiation is the only energy source supplying heat to the tank. A $20 \mathrm{~cm}$ thick rock wool insulation has been modelled in order to decrease storage losses. Storage tank volume is $7 \mathrm{~m}^{3}$, which is optimized for this application.

\subsection{Cooling tower}

The absorption chiller needs a rejection circuit to evacuate both energy flows (energy from collectors and from building). Heat rejection control is crucial to guarantee good performances of absorption chiller. The model used is Type 510 representing a closed cooling tower. According to the authors (Zweifel at al., 1995) it is able to find accurately the power rejected based on only one design point. This point has been found for an existing machine (AEC, 2007) with a nominal rejection power of $263 \mathrm{~kW}$.

Control of outlet water temperature is done by modifying the cooling tower fan speed. Assumption done here is that fan speed varies continuously from zero (when inlet temperature 
is $27^{\circ} \mathrm{C}$ ) to its nominal power $3.7 \mathrm{~kW}$ (when inlet temperature is $35^{\circ} \mathrm{C}$ ). In this way a low cooling tower return temperature (below $30^{\circ} \mathrm{C}$ ) can be achieved all over the year.

\subsection{Solar collector field}

Evacuated tube collectors (ETC) are used because of the slightly high temperature they can reach (i.e. flat plate collector are not so efficient for this application). Type 71 has been chosen to implement the manufacturer data (SCHOTT, 2003) including collector yield, incidence angle modifier and mass flow variation. Rules must be defined to size the collector field. The following hypothesis is selected for this study: the only available space is the flat roof of the building. A three floor building is then considered instead of twelve mentioned in paragraph 2. It leads to an available solar absorption area of $142 \mathrm{~m}^{2}$ per floor. Moreover, optimisation finds the best design of the collector field: four rows with $15^{\circ}$ slope and obviously oriented South. The size of the collector field clearly influences the solar fraction ( $\S$ 7.1). Hypothesis selected in this work lead to the value of around $2.5 \mathrm{~m}^{2}$ collector area per $\mathrm{kW}_{\text {cold }}$ nominal load $(50 \mathrm{~kW}$ see figure $14 \S 7.3)$. It is the average value of the installed solarair conditioning systems (Henning, 2007).

Shading is taken into account between rows by using a special model (Type 551). Finally, the solar loop is connected to the storage tank via a heat exchanger with $95 \%$ constant effectiveness.

Mass flow from collectors has been set to $30 \mathrm{~kg}$ per hour per collector area (Eicker, 2009). Mass flow modulation did not achieve significant energy savings (THOMAS et al., 2009b).

\subsection{Auxiliary gas boiler}

A gas boiler is used as backup when the storage tank top temperature is lower than the temperature given by the heating curve (figure 9). The gas boiler performance is defined (Stabat, 2007): yield at $100 \%$ load is $89.2 \%$; yield at $30 \%$ load is $88.2 \%$; losses at $0 \%$ load are $1.3 \mathrm{~kW}$. Interpolation is done between these three points. Rated power is $150 \mathrm{~kW}$ according to the maximal floor heating load. This device is switched OFF if there is no heating demand.

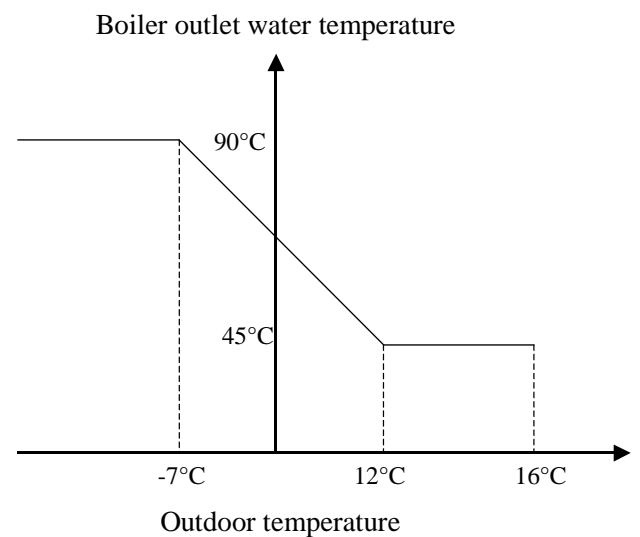

Figure 9: Boiler outlet water temperature set point (Stabat, 2007)

\subsection{Vapour compression chiller (VCC)}

As mentioned in the introduction, the back-up system for cooling is a classical vapour compression chiller. In the frame of IEA ECBCS a reversible air cooled heat pump (WESPER, 2005) was implemented into TRNSYS. The model consists in reading the manufacturer performance curves. This machine is exploited in this work to produce cold water at $7^{\circ} \mathrm{C}$. 
Vapour compression chiller has $105 \mathrm{~kW}$ cold power, its seasonal COP is 3.5 (including fans and pumps).

\subsection{Auxiliaries}

For pumps, no typical pressure drops values are found for the different circuits, pumps are not modelled as they were for distribution emission layer. Common energy consumption values are considered (Henning, 2008):

- $0.02 \mathrm{kWh}$ electricity per kWh thermal energy for solar system,

- $0.03 \mathrm{kWh}$ electricity per kWh thermal energy for heat rejection,

- $0.01 \mathrm{kWh}$ electricity per $\mathrm{kWh}$ thermal energy for absorption chiller.

These values include pumps consumptions and other auxiliaries such as cooling tower fans.

\section{CLIMATE}

TRNSYS software makes the link between the building and the meteorological data. The Paris Montsouris station is selected to run simulations. The common format "Typical Meteorological Year" (TMY2) is used. It includes dry bulb temperature, relative humidity, solar diffuse and global radiation, sun position, ... Paris climate is warm temperate, the monthly mean temperature and total solar radiation on horizontal are plotted on figure 10 .

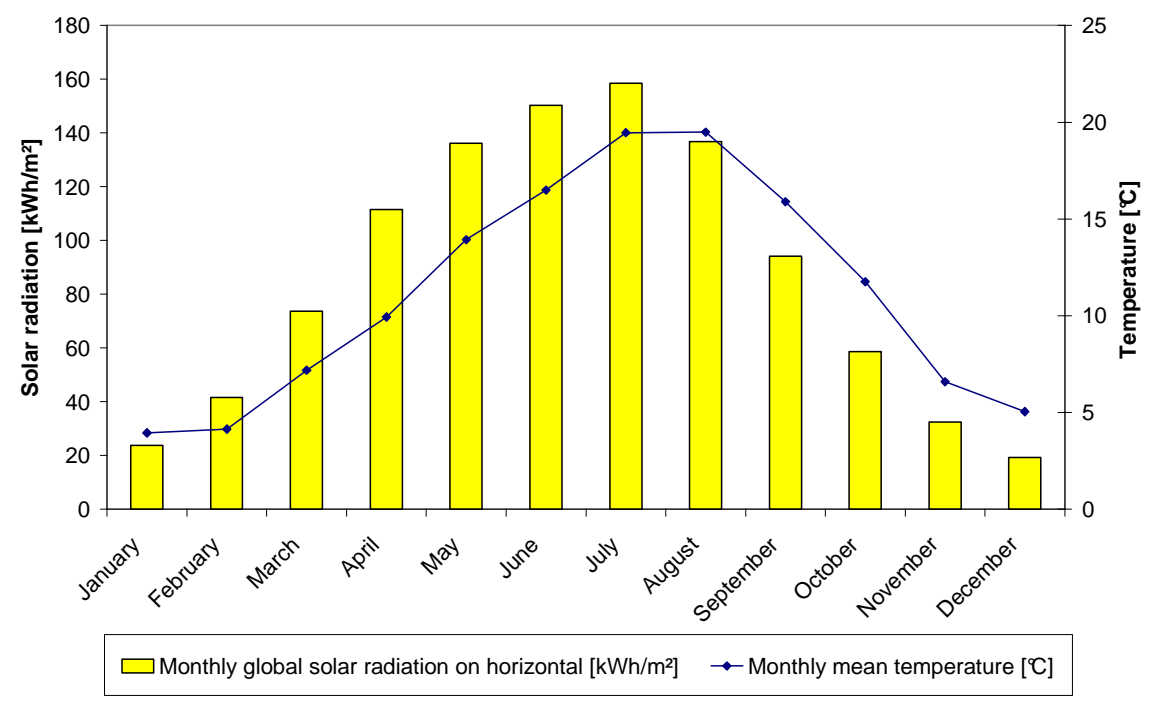

Figure 10: Paris TMY 2 data (yearly radiation on horizontal is $1036 \mathrm{kWh} / \mathrm{m}^{2}$ )

\section{RESULTS}

The building and HVAC devices presented below are simulated with TRNSYS using a 10 minutes time step. The simulation gives the opportunity to evaluate the energy consumption of the building. The results are presented and analyzed below. Three different time scales are considered for the heating and cooling consumption. The auxiliaries such as lighting, appliances and fans are treated separately ( $\$ 7.5)$. Comparison is achieved with a classical solar air-conditioning. Primary energy consumption is sometimes mentioned. To convert net energy (energy you pay to your energy supplier) to primary energy, multiplication factor is 2.5 for electricity, 1 for gas (Belgian values). These conversion factors depend on the country. For Germany it is 2.6 for electricity and 1.1 for natural gas (Kagerer, 2010) but mean European mix is 2.5 for electricity (Thür et al., 2010). 


\subsection{Yearly results}

Global results about building energy consumption for heating and cooling are presented below. Various energy flows are integrated all over the year and are presented in $\mathrm{kWh}$ per building internal area per year (figure 11): Boiler energy, Vapour compression chiller (VCC). These first results focus on net energy for heating and cooling with the $21-24^{\circ} \mathrm{C}$ set points. As mentioned in the previous paragraphs, solar energy is used both for heating and cooling. With solar air conditioning (SAC), there is a decrease of $22 \%$ of the energy consumption while net energy for cooling drops off $40 \%$. This last part has only a small impact on total building energy utilization. SAC implies additional electricity consumption ("Solar auxiliaries electricity"). On figure 11 can be seen the part of the heating and cooling load achieved by the solar system ("Heating load (solar)" and "Cooling load (ABS)"). The total heating load is higher with solar air conditioning then with classical air conditioning. It is due to higher temperature in heating network (higher losses) and less accurate control resulting from the water temperature variation. Solar energy used is $40 \%$ for heating and $60 \%$ for cooling.

The whole building consumption for heating and cooling is presented in figure 12 and table 3 . They include two simulations with two different set points for cooling. $24^{\circ} \mathrm{C}$ is commonly encountered in existing building while DIN 1946 regulation allows $26^{\circ} \mathrm{C}$ most of the time. Energy consumption is decreased by around $23 \%$ while applying solar air-conditioning. Additionally, set point variation has a slightly lower effect on energy use (5 to $9 \%$ decrease respectively for net and primary energy). For this location, the building heating has the greatest impact on energy consumption even when speaking about primary energy.

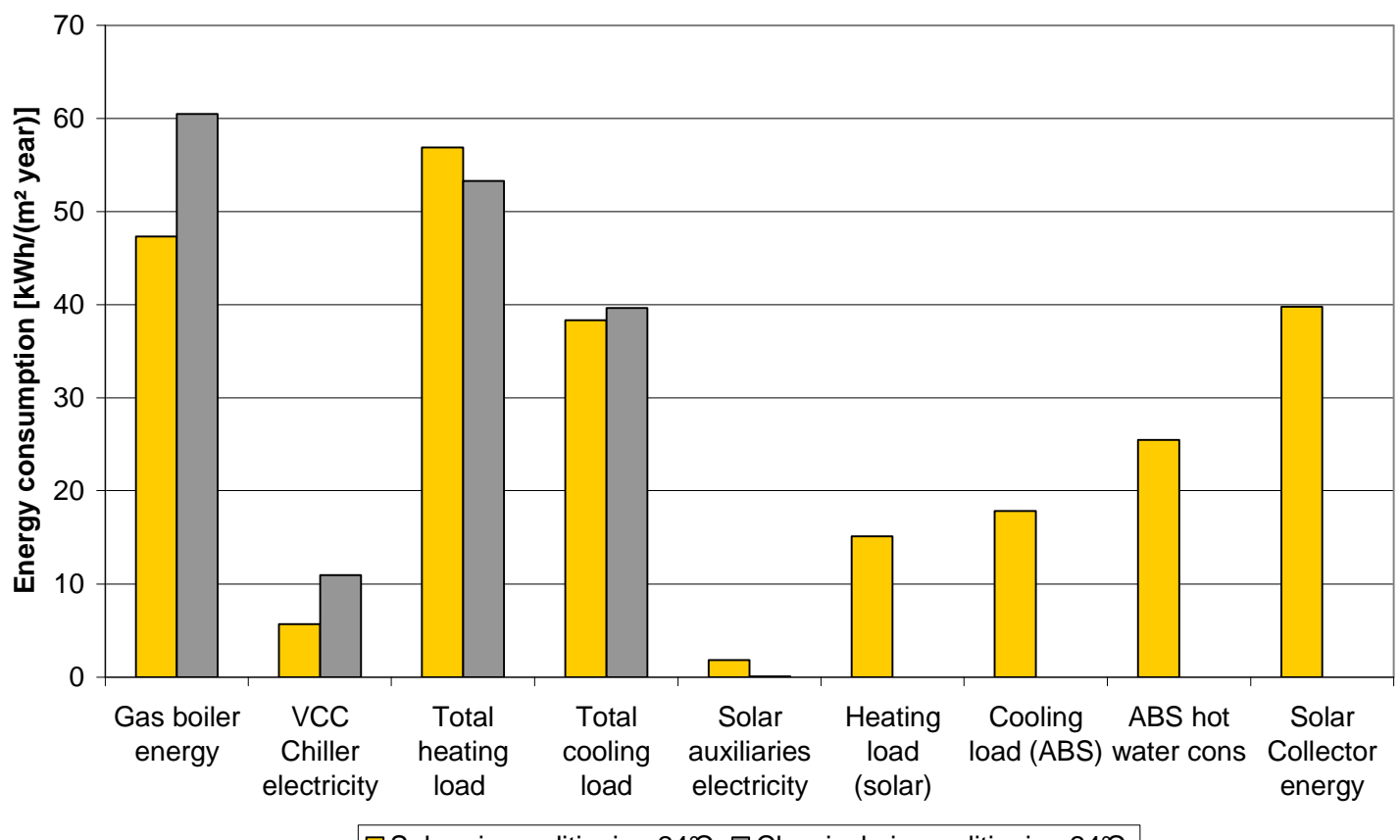

$\square$ Solar air conditioning $24^{\circ} \mathrm{C} \square$ Classical air conditioning $24^{\circ} \mathrm{C}$

Figure 11: Yearly net energy consumption for heating and cooling 


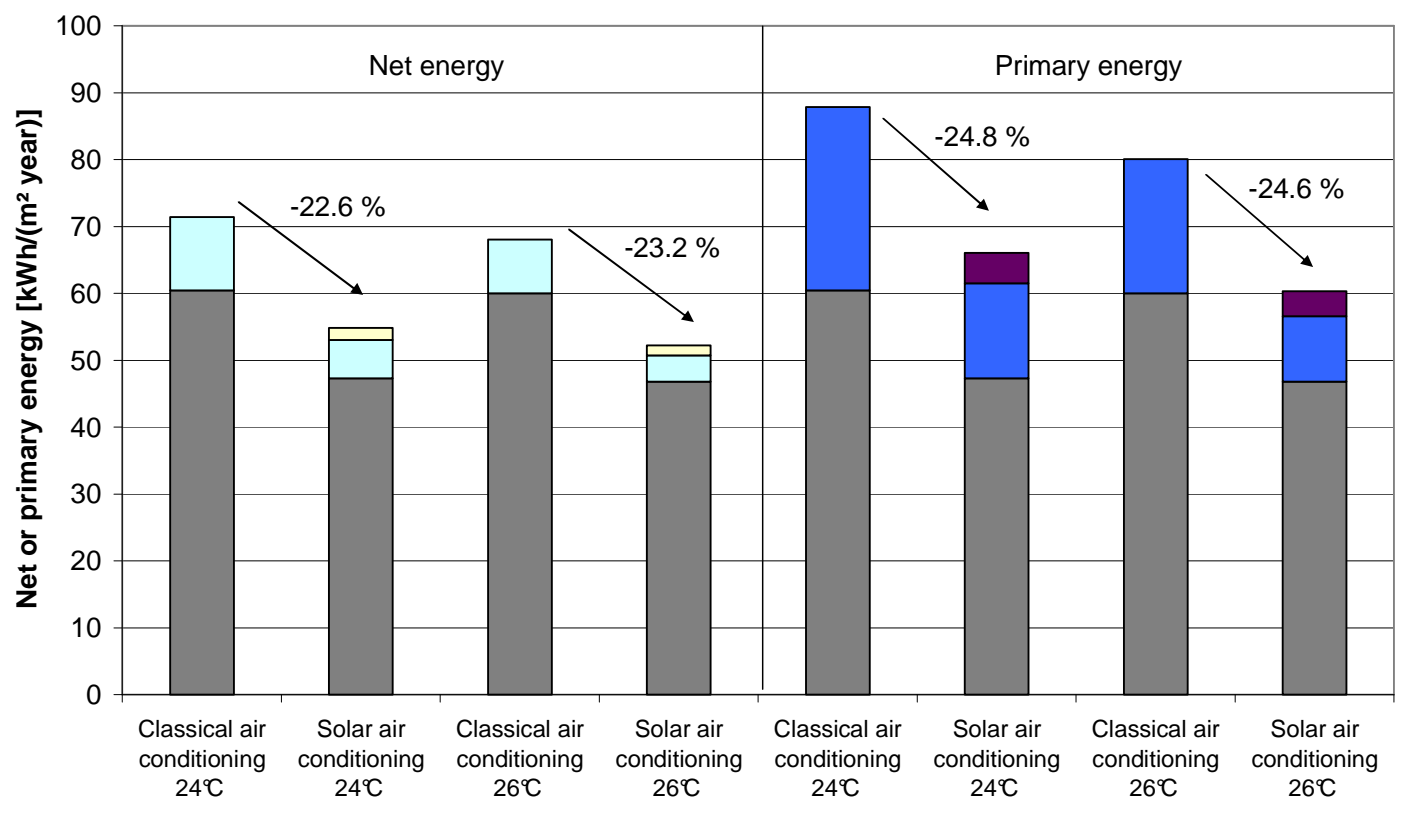

$\square$ Gas boiler energy $\square$ VCC chiller net $\square$ Solar auxiliaries net $\square$ VCC chiller primary $\square$ Solar auxiliaries primary

Figure 12: Yearly net and primary energy for heating and cooling

Other interesting figures can be introduced here. Generally the performance of a solar air conditioning system is specified by the solar fraction or by the energy savings per collector area (defined in \$5.4). Numerous solar fraction definitions can be found; the first one (equation 4) is the global solar fraction for heating and cooling based on energy consumed. The second definition is the solar fraction for cooling (equation 5) or heating (equation 6), it is defined according to the load.

Table 3: Yearly net energy consumption for heating and cooling

\begin{tabular}{|c|c|c|c|c|}
\hline Unit : $\left[\mathrm{kWh} /\left(\mathrm{m}^{2}\right.\right.$ year $\left.)\right]$ & $\begin{array}{c}\text { Gas boiler } \\
\text { energy }\end{array}$ & $\begin{array}{l}\text { VCC } \\
\text { chiller }\end{array}$ & Solar auxiliaries & Sum of all \\
\hline Solar air-cond. $24^{\circ} \mathrm{C}$ & 47.33 & 5.68 & 1.81 & 54.83 \\
\hline Solar air-cond. $26^{\circ} \mathrm{C}$ & 46.80 & 3.91 & 1.51 & 52.23 \\
\hline Classical air-cond. $24^{\circ} \mathrm{C}$ & 60.46 & 10.98 & 0.00 & 71.44 \\
\hline Classical air-cond. $26^{\circ} \mathrm{C}$ & 60.05 & 8.01 & 0.00 & 68.06 \\
\hline
\end{tabular}

$$
\begin{aligned}
S F & =\frac{\text { Collector energy }}{\text { Collector energy }+ \text { Boiler cons. }+ \text { VCC cons } .} \\
\text { SF Cooling } & =\frac{\text { Load met by ABS chiller }}{\text { Load met by ABS chiller }+ \text { Load met by VCC chiller. }} \\
S F \text { Heating } & =\frac{\text { Load met by solar storage }}{\text { Load met by solar storage }+ \text { Load met by boiler. }}
\end{aligned}
$$


The performance indicators related to solar air-conditioning are presented in table 4. Nearly forty percents of total energy consumed in the building is coming from solar collectors. Besides, nearly half of the cooling load is satisfied by the absorption chiller. Collector energy seems to be smaller than common solar applications. It can be explained by the high temperature in panels (decreasing yield) and no consumption during the weekend. If this office building was occupied during the weekend the collector energy would reach $400 \mathrm{kWh}$ per square meter collector (for $24^{\circ} \mathrm{C}$ set point). Finally, the yearly thermal COP for absorption chiller is much closed to the nominal value. The electrical COP reveals the ratio between the cooling energy and solar auxiliary devices consumption. This indicator can be compared with vapour compression chiller COP.

Table 4: Solar air-conditioning performance indicators

\begin{tabular}{|c|c|c|c|c|c|c|}
\hline Case & $\begin{array}{c}\text { Solar } \\
\text { fraction }\end{array}$ & $\begin{array}{c}\text { Solar } \\
\text { fraction } \\
\text { Cooling }\end{array}$ & $\begin{array}{c}\text { Collector } \\
\text { energy }\end{array}$ & $\begin{array}{c}\text { Primary } \\
\text { energy } \\
\text { savings per } \\
\text { collector area }\end{array}$ & $\begin{array}{c}\text { Yearly } \\
\text { ABS } \\
\text { COP }\end{array}$ & $\begin{array}{c}\text { Elec. } \\
\text { COP }\end{array}$ \\
\hline Units & {$[-]$} & {$[-]$} & {$\left[\mathrm{kWh} / \mathrm{m}^{2} \mathrm{coll}\right]$} & {$\left[\mathrm{kWh} / \mathrm{m}^{2} \mathrm{coll}\right]$} & {$[-]$} & {$[-]$} \\
\hline $24^{\circ} \mathrm{C}$ Set point & 0.43 & 0.47 & 350.19 & 192.12 & 0.70 & 9.85 \\
\hline $26^{\circ} \mathrm{C}$ Set point & 0.41 & 0.49 & 310.80 & 173.44 & 0.67 & 8.86 \\
\hline
\end{tabular}

\subsection{Monthly results}

On a monthly basis (figure 13), some significant things can be emphasized. For the building heating, there is a load all over the year but solar fraction heating is 1 during four months. No back up system is required for heating during this period. For the cooling side, each month except January requires cooling energy. Nevertheless winter months do not have enough solar energy to run the absorption chiller. Solar fraction cooling is never higher than 0.7 , a back up system is involved for these eleven months.

The other definition of solar fraction informs us about the solar energy related to other energy consumptions (boiler and VCC chiller). It is higher than $80 \%$ during six months. By reducing slightly the both loads, it could be possible to achieve $100 \%$ half of the year. 


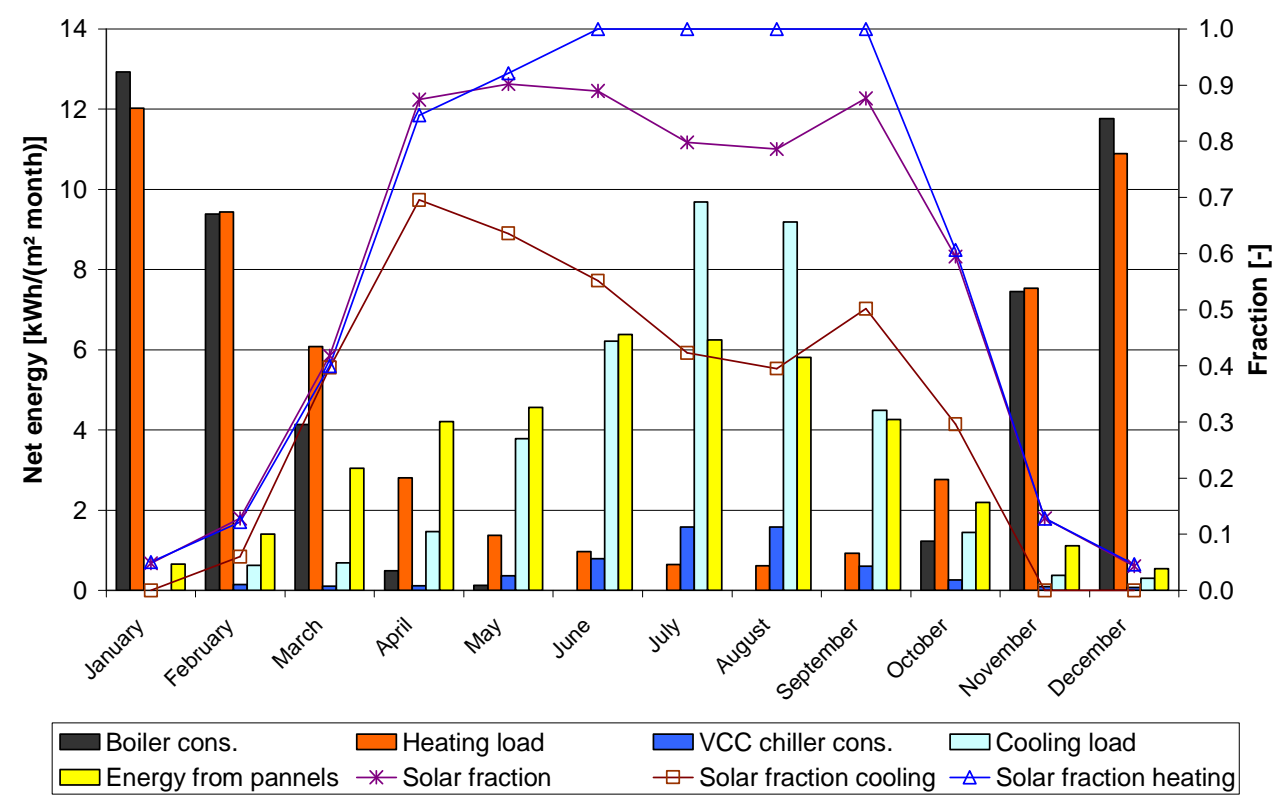

Figure 13: Monthly results

\subsection{Daily results}

Distribution of cooling energy between both chillers can be determined by a daily analysis. For days with low cooling load, the cooling load is generally satisfied by the absorption chiller only. Some days have higher cooling load. For the hotter days, the variation of the cooling load through the day is presented on figure 14. It is characterized by a peak value at the beginning of cooling system operation, an increasing cooling load until 5pm and a decrease to the end of the occupation period. This kind of curve is systematically encountered from May to September. For slightly hot day, the cooling load from 7am to 4-6pm is handled by the absorption chiller. The early morning peak implies a higher minimal temperature for absorption chiller while the end of the day is less sunny; it leads to the start of VCC chiller.

For a really hot day such as the $9^{\text {th }}$ of July (figure 14), both chillers have an alternate operation. Temperature at the top of the water storage "TfeedABS" varies with the contribution of the collector field and the water drawing of the absorption chiller. As soon as the storage temperature is higher than the threshold "TminABSchiller+3" (see §5.1), the absorption chiller starts. If the temperature is not high enough to operate the absorption chiller, it stops. There are potentially between 10 and 20 switches between both chillers during one day

Room temperature is not displayed but matches the set point $\left(24^{\circ} \mathrm{C}+/-0.5^{\circ} \mathrm{C}\right)$ every time. 


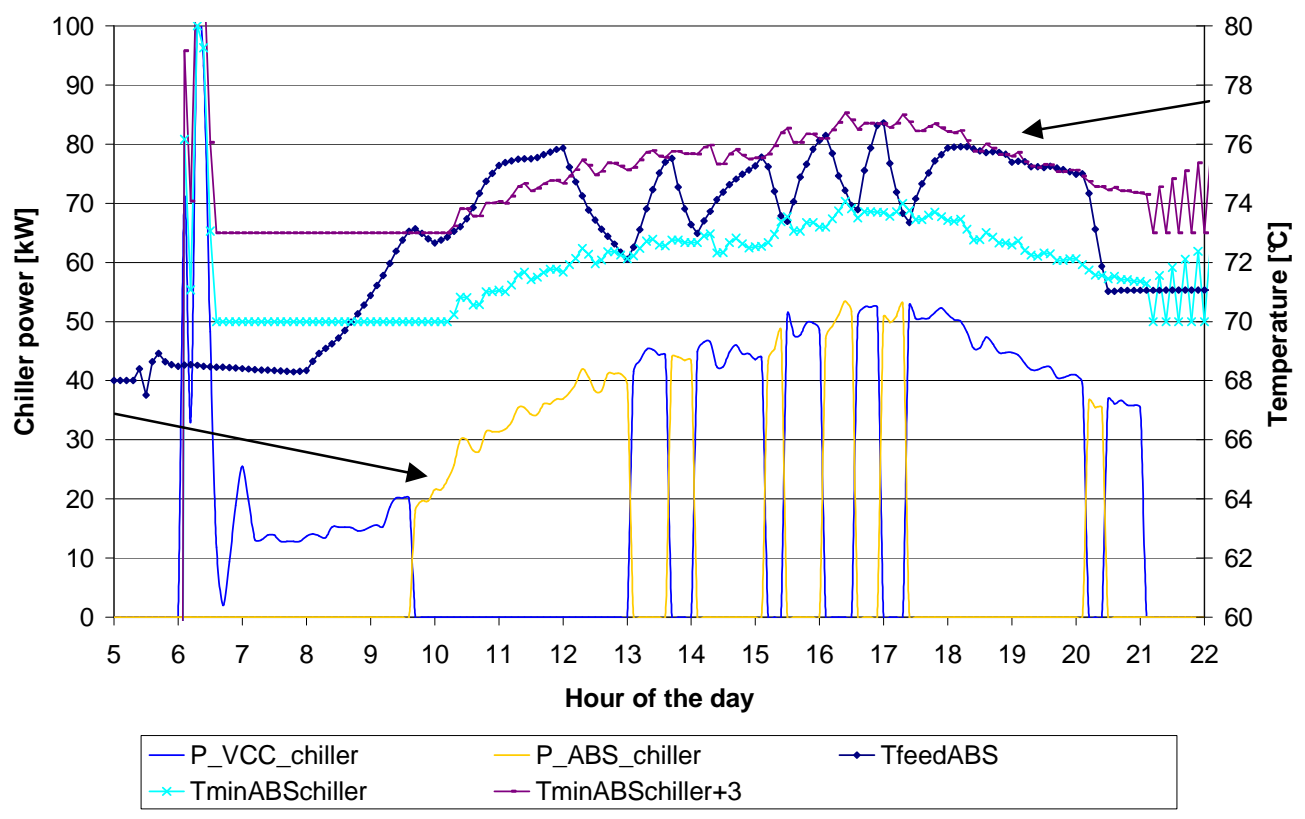

Figure 14: Cooling power for the $9^{\text {th }}$ July (very hot day)

\subsection{Building auxiliaries consumption}

Auxiliaries include electricity consumption of appliances (computers, printers, ...), lights, fans from ventilation system, fans from fan coil units, both pumps for heat and cold distribution. The yearly consumption is mentioned in table 5 related to the floor area. Energy consumption of auxiliaries is nearly the same as the energy consumed by heating and cooling production devices. However, from the primary energy point of view, it has a much larger impact; it is around twice as much. It means that two third of the primary energy consumption of the building is dedicated to the auxiliaries. Light and appliances are the most important. The assumptions for auxiliaries computation come from Stabat (2007) and are expressed in $\$ 3$.

Table 5: Auxiliaries consumption

\begin{tabular}{|c|c|c|c|c|c|c|c|c|}
\hline & $\begin{array}{c}\text { Auxiliaries } \\
\text { sum } \\
\text { (primary) }\end{array}$ & $\begin{array}{c}\text { Auxiliaries } \\
\text { sum } \\
\text { (elec.cons.) }\end{array}$ & $\begin{array}{c}\text { Hot } \\
\text { pump }\end{array}$ & $\begin{array}{c}\text { Cold } \\
\text { pump }\end{array}$ & $\begin{array}{c}\text { FCU } \\
\text { Fans }\end{array}$ & Ventilation & Appliances & Light \\
\hline$\frac{k W h}{m^{2} \text { year }}$ & 180.03 & 72.01 & 1.09 & 10.40 & 8.08 & 3.72 & 25.56 & 20.36 \\
\hline
\end{tabular}

The artificial lighting is adjusted regarding to the available natural light for workers (explanation in $\S 3.3$ ). It is clearly an energy saving measure. If it was not implemented, lighting consumption would have been $48.44 \mathrm{kWh} / \mathrm{m}^{2}$. The influence on heating and cooling load is significant; they are respectively $42.1 \mathrm{kWh} / \mathrm{m}^{2}$ and $9.39 \mathrm{kWh} / \mathrm{m}^{2}$ instead of 47.3 $\mathrm{kWh} / \mathrm{m}^{2}$ and $5.68 \mathrm{kWh} / \mathrm{m}^{2}$ (solar air-conditioning case with $24^{\circ} \mathrm{C}$ set point). Electrical internal gains have therefore a double impact on energy utilization: their own consumption and the increase in cooling required energy. 


\section{CONCLUSION AND PROSPECTS}

A comprehensive coupling between an office building and a solar air-conditioning application was presented, and provided results about the whole energy consumption. A typical European office building was defined closely to the real life operation. As modelling hypothesis influence very much the energy consumption, all the parameters and the characteristics of the model are described. Moreover, almost all air-conditioning devices have their parameters taken in manufacturer's data sheets.

The simulation includes many models, the structure becomes easier understandable by dividing the problem into three parts: building; emission \& distribution; production \& storage. It is also done in this way in the TRNSYS environment. Its modularity gives the possibility to optimize or replace some parts in further work.

The comparison between classical and solar air-conditioning was achieved for two cooling set points. The first one is commonly observable in buildings while the second one is coming from a standard. Classical air conditioning has a total net energy consumption of around 70 $\mathrm{kWh} /\left(\mathrm{m}^{2}\right.$ year $)$ while solar air-conditioning falls to the order of magnitude of $50 \mathrm{kWh} /\left(\mathrm{m}^{2}\right.$ year). A decrease of $22-23 \%$ is thus encountered. It is a considerable decrease in energy consumption according to the heat and cold production but a lighter effect on the total building energy consumption. Besides, the higher cooling set point shrinks the energy consumption by around 5\%. The solar air conditioning is more interesting when the building is moderately cooled down.

The solar collector size was set according to roof size. It is a crucial parameter of the solar airconditioning system. Energy savings are directly linked to its value; it is then possible to save much more energy by installing an enormous solar collector field. If there is neither space nor economical limit, the solar auxiliaries would be an important part of the energy balance. The electrical COP is then an excellent indicator for solar system energy performance.

The auxiliaries consumption are also computed considering a common building use. One of the key facts is that auxiliaries consumption in terms of primary energy is always really higher than energy used for heating and cooling. As shown for lighting, their use adds electricity consumption and increases cooling load in the room. Reducing the auxiliaries consumption by using energy efficient electrical devices seems to be very interesting.

This work reveals some limitations of the current simulation environment. Absorption chiller model is not including any dynamic effects nor part load performance decrease. Therefore, the yearly COP is certainly overestimated. This environment has been built step by step since two years, some optimization previously done on solar collectors, storage and other parameters could be reviewed in relation to the recent development. Pipe and pumps could be modelled for the solar loop and absorption chiller; it will certainly lead to a more accurate solar auxiliaries evaluation. Finally, handling of latent load is done in a very simple way independently of fan coil operation. It should be added to the fan coil unit model to couple sensible and latent loads.

The simulation environment is a comprehensive building and systems model, it allows evaluating the potential energy savings by modifying some parameters or by implementing new control strategies for lighting, ventilation, solar protections, heating, cooling ... 


\section{REFERENCES}

AEC Cooling Tower Systems FG 2004, 2007. Heat \& Cool FG cooling tower http://www.aecinternet.com/images_products/files/FG\%20Cooling\%20Tower\%20LO.pdf (last visit on 16th June 2010)

Alessandrini J.M. et al., 2006. Impact de la gestion de l'éclairage et des protections solaires sur la consommation d'énergie de bâtiments de bureaux climatisés, Climamed, Lyon, France.

Barbosa R.M., Mendes N., 2008. Combined simulation of central HVAC systems with a whole-building hygrothermal model, Energy and Buildings 40 pages 276-288.

CARRIER, 2007. Fan Coil Unit Carrier 42N documentation, http://www.ahicarrier.com/pdf/PD/42N_PD.pdf (last visit on 16th June 2010), Villasanta, Italy.

Casals X.G., 2006. Solar absorption cooling in Spain: Perspectives and outcomes from the simulation of recent installations. Renewable energy 31 pages 1371-1389

Eicker U. , Pietruschka D., 2009. Design and performance of solar powered absorption cooling systems in office buildings. Energy and Buildings 41 pages 81-91

Henning, H.-M. , 2007. Solar-Assisted Air-Conditioning in Buildings, A Handbook for Planners (Second Revised Edition), Springer-Verlag/Wien

Henning, H.-M., 2008. Solar Cooling Components and Systems - an Overview, Solar AirConditioning international seminar, June 2009, Munich, Germany.

Herold, K.E., Radermacher R. and Klein S.A., 1996 Absorption Chillers and Heat Pumps. 1st edition, CRC-Press

Kagerer, F., Herkel, S., 2010. Concepts for Net Zero Energy Buildings in refurbishment projects. ISES IEA-SHC Eurosun 2010 Conference, Graz, Austria

Klein, S.A., 2007. TRNSYS 16 Program Manual. SEL, University of Wisconsin, Madison USA

SHOTT ETC 16, 2003, SCHOTT Evacuated Tube Collector ETC16

http://www.schott.com/uk/english/download/solar_thermal_rd319.pdf (last visit on 16th June 2010)

Sparber W. and Napolitano A., 2009. IEA-SHC Task 38. List of existing solar heating and cooling installations. Available online http://iea-shc-task38.org/documents/monitoring2 (last visit: 10 June 2010)

Stabat P. 2007. IEA48 - Description of Type 1c air-conditioned office buildings for simulation test, IEA-ECBCS Annex 48 working document. 
Thomas S., André P., 2009a. Dynamic simulation of a complete solar assisted airconditioning system in an office building using TRNSYS. IBPSA Building Simulation conference 2009, Glasgow, UK.

Thomas S., André P., 2009b. Control strategies study of a complete solar assisted air conditioning system in an office building using TRNSYS. OTTI Solar Air-Conditioning conference 2009 proceedings, Palermo, Italy.

Thür A. 2010. Monitoring Program of Small-Scale Solar Heating and Cooling Systems within IEA-SHC Task 38 - Procedure and First Results. ISES IEA-SHC Eurosun 2010 Conference, Graz, Austria

TRNSYS simulation studio (2006), Version 16.00.0038 Licensed to University of Liège

WESPER VLH HE 804, 2005. Air-to-Water Reverse Cycle Heat Pumps VLH 504 to 1204 Technical Brochure, Wesper S.A.S., Pons, France

YAZAKI, 2008. Water Fired Chiller/Chiller-Heater WFC-S Series documentation http://www.yazakienergy.com/waterfiredperformance.htm (last visit on 16th June 2010), Yazaki Energy Systems Inc., Plano, Oklahoma, USA

Zweifel G., Dorer V., Koschenz M. and Weber. A. 1995. Building Energy and System Simulation Programs: Model Development, Coupling and Integration. Building simulation conference 1995, Madison, Wisconsin, USA. 